\title{
Country of Origin as a Constraint to Internationalization
}

\author{
Raquel Meneses, ${ }^{1} *$ Sara Santos $^{2}$ \\ ${ }^{1,2}$ School of Economics and Management, University of Porto, Porto, Portugal
}

\section{ABSTRACT}

Objective - Globalization has enabled the increase of competitiveness and opportunities for companies to sell their goods to worldwide consumers. Due to the wider range of products offered and increasing similarity of those products, the country of origin becomes an important variable when studying the evaluation process of foreign products. The origin of a product acts as a mark of quality, which ultimately influences the purchase intentions of consumers. When negative, this may act as a constraint on internationalization, making it difficult to accept a product from a certain origin. There is, therefore, a gap in how companies can mitigate and overcome a negative country of origin effect (COE). This study seeks to fill this gap and suggest strategies to overcome this issue.

Methodology/Technique -The methodology applied in this study is the Grounded Theory. The data was collected from interviews with Portuguese entities, so different cases can be compared and discussed. Although Portugal's image has changed over time, there remains a stigma associated with it. The most recent financial and political crisis has damaged the perception of Portugal in the international sphere, hence, it has been selected for the formation of a negative COE.

Findings and Novelty - Some firms currently have existing strategies to resist the negative effect of country of origin, such as improvement of brand awareness, credibility and international visibility. To achieve that, companies must adopt a wide set of strategies which involve both defensive and offensive approaches.

Type of Paper: Empirical.

Keywords: Country of Origin; Country of Origin Effect; Internationalization; Constraints; Grounded theory.

Reference to this paper should be made as follows: Meneses, R.; Santos, S. (2019). Country of Origin as a Constraint to Internationalization, J. Bus. Econ. Review, 4 (2): 105 - 113 https://doi.org/10.35609/jber.2019.4.2(5)

JEL Classification: F6, F60, F69.

\section{Introduction}

Globalization has enabled for the increase of competitiveness and opportunities for companies to sell their goods to worldwide consumers. Due to the wider range of products offered and the increasing similarity of these products, country of origin becomes an important variable when studying the evaluation process of foreign products (Jiménez \& San Martín, 2010). Country of origin refers to a product's "home country" where it is assembled and produced (Al-Sulaiti \& Baker 1998; Rezvani et. al., 2012).

\footnotetext{
* Paper Info: Revised: March 18, 2019

Accepted: June 18, 2019

* Corresponding author: Raquel Meneses

E-mail: raquelm@fep.up.pt

Affiliation: School of Economics and Management, University of Porto, Porto, Portugal
} 
Previous studies have shown that the country of origin has an influence on consumers' attitudes and behaviour as well as, for example, on purchase intentions (Yunus \& Rashid, 2016). When the effect of the country of origin is negative, consumers do not typically purchase products from that origin, and in fact, this effect can become a constraint to internationalization. Hence, as Costa et. al. (2016) concludes, firms must understand how country of origin impacts their products and develop the right strategies to combat any negative effect that may flow from it. The primary purpose of this study is to understand how companies can mitigate or overcome a negative country-of-origin effect (COE) with a particular focus on the Portuguese furniture industry, since, despite its fast-growing reputation in the international context, it still faces difficulties due to its country of origin.

\section{Literature Review}

As a result of the increased supply from varied countries and intense competition, consumer perceptions and sensitivity to country of origin (COO) have been changing (Agrawal \& Kamakura, 1999). Consumers tend to evaluate a certain product using multiple factors during their decision-making process, grounded on their knowledge, experiences and information. According to Gregory and Ross (1994), country-of-origin effect (COE) refers to the influence country of origin of certain products or services has on consumers' decision processes. COE is an example of stereotyping organizations (Schatzle \& Jacob, 2019) and products (Suh et. al., 2016), based on consumers' perceptions of a certain country due to their previous experience, personal and political beliefs and prior knowledge (Knight, 1999). The produced effect can be a null, positive or negative perception of a country (Silva \& Saraiva, 2016). Consequently, products with identical features made in different countries are not evaluated equally by consumers (Bilkey \& Nes, 1982; Schooler, 1965).

Maheswaran (1994) claims that consumers resort to cues during the decision-making process; some are considered intrinsic while others are extrinsic. Intrinsic cues are those directly related to a certain product such as, for example, the physical and inherent product features. Extrinsic cues are more intangible and not fundamental to performance such as $\mathrm{COE}$, price, brand, warrant terms, distribution channels, etc. (Maheswaran, 1994; Costa et. al., 2016). Intrinsic cues generally help differentiate one product from another, hence, in the absence of, for instance, a lack of information or no prior purchases, consumers tend to rely on extrinsic cues (Jacoby et. al., 1977). When the COE cue is presented, the effects of COE on the cognitive processes are observed in two different ways (Hong \& Wyer, 1989; Han, 1989): the halo effect and the summary construct.

The halo effect occurs when consumers are not familiar with the product and/or its country of origin. Therefore, due to the lack of information about a certain product, consumers rely on their beliefs, which affects their overall evaluation (Johansson et. al., 1985) and can be positive or negative depending on the consumers' feelings and beliefs about the country. Usunier and Cestre (2007) state that the influence of COO tends to be stronger when consumers are not familiar with a product category, as buyers use country of origin as an indicator of quality (Cheah et. al., 2018).

On the other hand, when consumers are familiar with a product or service, the importance of COO tends to diminish (Usunier \& Cestre, 2007). The summary construct establishes when consumers are familiar with a country's product and resort to their stereotypical beliefs, experiences and overall knowledge regarding that country (Han, 1989). As a summary construct, the information about the country of origin is used as a proxy and summarizes other information on attributes already known or expected. Andéhn and Decosta (2018) summarize the $\mathrm{COE}$ in a baseline model, where they consider $\mathrm{COE}$ as "the relationship between place, commodity association and consumption, and their outcome as it pertains to consumption" (885). The supply side is completely omitted. Nevertheless, businesses need to deal with COE every day.

The process of internationalization is not always easy; difficulties may arise from both internal and external barriers (Leonidou, 2004). As firms cannot directly control external barriers, this can represent a major challenge. Consequently, firms with a negative COE face even more difficulties than those with a positive effect. Therefore, new strategies are needed to provide unique and distinctive assets to develop a 
solid competitive position (Silva \& Saraiva, 2016). Relatively little research into the right strategies according to different $\mathrm{COE}$ has been conducted. When $\mathrm{COE}$ is positive, companies can benefit from it, emphasizing their country of origin (Niss, 1996; Laroche et. al., 2005). In that situation, COE can be used as a source of competitive advantage (Suter et. al., 2018). On the contrary, when COE is negative companies try to neutralize it, emphasizing other attributes such as price or quality (Laroche et. al., 2005).

According to Eden and Miller (2004), the entry mode choice can determine the success of an internationalization process. Joint-ventures, for example, with the right partners, can be a way of reducing the unfamiliarity and discrimination hazards as well as a possible negative COE (Eden \& Miller, 2004). Moreover, the offensive strategies suggested by Luo et. al. (2002) and the theory of the secondary associations enhanced by Keller (1993) can prove to be very effective strategies to mitigate a negative COE.

Keller's perspective states, "Secondary associations may arise from primary attributes associations related to the company, the country of origin, the distribution channels, a celebrity spokesperson or endorser, or an event" (Keller, 1993). The COO is itself a secondary association. When consumers recognize the country of origin of a certain brand, it may result in positive or negative feelings (Shahin, 2012). Firms that cannot be benefited by their origin, must resort to other secondary associations that can enhance their market position. Such associations can be company and associated brands, distribution channels, celebrity spokespersons and events.

Offensive mechanisms seek the firms' adaptation to the environment of the host country and the increase of its organizational legitimacy. The purpose is to reduce the firm's 'foreign' factor as much as possible and transform it into a local one (Luo et. al., 2012). As such, even firms with a negative COE can reduce their liabilities by adopting the following four mechanisms: (1) local networking, (2) resource commitment, (3) legitimacy improvement, and (4) input localization.

\section{Research Methodology}

The Grounded Theory consists of a qualitative methodology that seeks patterns of action and interaction between various types of social units to generate theory. It is based on theory development (through an inductive process) and not on theory verification (Glaser \& Strauss, 1967). These are the main reasons we adopted the Ground Theory methodology. Even when considering the same country of origin, COE varies across classes of products (Costa et. al., 2016); this research focuses on one industry only - the Portuguese furniture industry.

The interviews were the main instrument for data collection. Semi-structured interviews were used to conduct the interviews more naturally. The sample is composed of eight furniture companies (as heterogeneous as possible) and one business association. Table 1 presents the interviewed entities and the job positions of the corresponding respondents.

Table 1. Interviewed Entities

\begin{tabular}{|l|l|l|}
\hline Company/Brand/Institution & Participant & Job Position \\
\hline ADN Furniture (ADN) & Vitor Nogueira - VN & CEO \\
\hline Stylish Club from Jota Barbosa & $\begin{array}{l}\text { Joaquim Barbosa - JB } \\
\text { Samuel Peixoto - SP }\end{array}$ & $\begin{array}{l}\text { CEO } \\
\text { Foreign Markets Director }\end{array}$ \\
\hline Meia Madeira & Fernando Sousa - FS & CEO \\
\hline Pregoo Upholstery & Ricardo Lourenço - RL & General Director \\
\hline $\begin{array}{l}\text { Associação Empresarial Paços de } \\
\text { Ferreira* }\end{array}$ & João Begonha - JoB & President \\
\hline Viriato Hotel Concept & Carla Rocha - CR & Commercial Director \\
\hline DuCampus & João Campos - JC & Managing Partner \\
\hline Company X** & Miss Y & Project Manager \\
\hline
\end{tabular}




\begin{tabular}{l|l|l|}
\hline GonçalRocha & Paulo Rocha - PR & CEO \\
*Business Association from Paços de Ferreira \\
** Anonymous
\end{tabular}

\section{Results}

According to the methodology used, the empirical cases are sequentially analysed to allow the researcher to create concepts through the coding process and generate categories. These categories are constantly compared and connected to each other so the theoretical framework can be redefined. The resulting categories (Table 2) can support and extend the theoretical framework.

Table 2 - Strategies to Overcome/Mitigate COE

\begin{tabular}{|l|l|l|}
\hline Name & Sources & References \\
\hline From Literature & & \\
\hline Celebrities and endorsements & 1 & 2 \\
\hline Distributors and key partners & 9 & 15 \\
\hline Events (Trade fairs and other network events) & 8 & 14 \\
\hline Linkages with other brands & 1 & 5 \\
\hline Emerging & & \\
\hline Brings customers to Portugal & 2 & 7 \\
\hline Choosing a brand with foreign name & 6 & 11 \\
\hline Rely on public funds & 2 & 4 \\
\hline Associativism & 6 & 8 \\
\hline Creation of local companies & 1 & 1 \\
\hline Coopetition & 1 & 1 \\
\hline Develop and promote the brand "Made in Portugal" & 1 & 4 \\
\hline Education and innovation investment & 2 & 7 \\
\hline Great portfolio & 3 & 6 \\
\hline International mission / Roadshows & 4 & 4 \\
\hline Internet and social media & 4 & 9 \\
\hline Word-of-mouth & 4 & 5 \\
\hline
\end{tabular}

The most common strategies to overcome the constraints to internationalization include: Distributors and Key Partners, Events and Associativism. With respect to Distributors and Key Partners, the interviewees stated that when entering into a new market, they mainly focus on the key players in the market to be able to set up their business activities faster while reducing their exposure to risk. Events such as international trade fairs and specific industry events are an effective way of promoting the companies name and products and contributes to establishing relationships with different market players. Lastly, the association to local business institutions was also widely mentioned by the respondents as an important tool to promote and establish a positive image of the Portuguese furniture-manufacturing sector.

\section{Discussion}

Although most firms do not directly admit that their Portuguese origin can evoke negative perceptions and jeopardize their internationalization process, most of them reveal some important cues regarding this matter. Firms enhance the quality of their products and state that international players recognize this quality. However, VN, SP, JoB, JC and PR state that Portuguese companies cannot charge a high price for their 
products: "Customers really appreciate our products and our design but, at the same time, they appreciate our products because of the low price" (SP).

Miss Y, JoB and PR tell interesting stories about real situations involving foreigners' negative perceptions of the Portuguese origin. Miss Y reports that Company X felt this negative perception during the first years of its activity. Thus, they suffered some losses to prove the quality of their products and to affirm themselves as a brand: "We were applying for a project to furnish a hotel where most of the candidate companies were Italian. Companies, after receiving the approval, could start producing a fourth model (paid by the hotel) to exhibit later. The Company X' application was rejected and only three Italian companies were accepted. Since they did not want to lose the opportunity to do their first business, the company produced the fourth model for free to be able to expose it along with the other models manufactured by the other candidates. The company had a loss of about 300 thousand euros and ended up exposing the fourth model in a corridor since there was no space left. In the end, the hotel chose our project because they recognized its quality and the price" (Miss Y).

\subsection{Strategies to overcome internationalization constraints}

To overcome the constraints to internationalization, firms are forced to adopt strategies to overcome them and thrive within the international market. The two most commonly mentioned categories (Distribution and Key Partners and Events) have already been explored in existing literature. As per the strategies proposed by Keller (1993) from the enhancement of Secondary Associations and by Luo et. al. (2002) from the Offensive Mechanisms, local networking and distribution channels prove to be a very effective way to mitigate a given constraint. All nine respondents established relationships of cooperation with local distributors and commercial agents.

According to the respondents, such collaboration proved and still proves to be extremely functional in the first years of a firm's internationalization process because commercial agents can provide relevant information about the business as well as establish great and important business connections. These tools allow firms to reduce their initial liability of 'foreignness' and liability of 'outsidership' by changing the perception of their firm to one that is "less foreign". This kind of collaboration also enhances the process of legitimacy, which, in turn, can minimize a possible negative COE (Vahlne et. al., 2002; Johanson \& Vahlne, 2009).

According to PR, this kind of collaboration proves to be helpful in shortening the entry phase and spreading market growth. However, over the years, "firms must become independent from such entities, so their commercial margins cannot be affected anymore" (PR). The second biggest slice of this pie chart concerns Events. Once again, the model proposed by Keller (1993) is evoked, based on the enhancement of Secondary Associations. Most Portuguese firms exhibit their products at international trade fairs or through roadshows (DuCampus, Preggo Upholestry) as this is the most effective way to establish the quality of Portuguese products as well as search for potential clients and key partners. Moreover, there are others specific events that can be even more effective than trade fairs. Another way to gain customers is, according to FS, by bringing them to Portugal. Meia Madeira tries to sell its products as well as sell its country. Its CEO believes that by doing this, it is improving the label "Made in Portugal" and developing the domestic economy.

Choosing and creating a brand with a foreign name could also be a good way to hide and mitigate the origin of a country (Thakor, 1996). This is the reason most of the interviewed firms managed to associate a brand with a foreign name to reach premium markets. Those who keep their domestic name (Portuguese name) usually export to Portuguese speaking African countries and/or direct a significant part of production to the domestic market (Meia Madeira, GonçalRochas).

Internet and social networks are also commonly mentioned by some of the respondents (ADN, Preggo Upholstery, GonçalRochas): "Social networks are considered a key factor in our communication strategy. All our sellers have a professional profile on many social networks. It allows our customers and potential ones to 
feel closer to us" (RL). Most of the respondents acknowledged that some sector associations have an important role in the establishment of relevant connections (local marketing firms, events planners, among others), as well as the improvement of the construction and dynamization of the label "Made in Portugal".

There are other strategies suggested in the existing literature as well as empirical evidence in support, such as celebrity associations and links with other known brands (Preggo Upholstery), coopetition among Portuguese firms (ADN), innovation (GonçalRochas) and educational investment (AEPF, GonçalRochas).

\section{Conclusion}

Research of the last few decades have sought to document the influence of the origin of products on consumer perceptions and evaluations as well as develop investigations that involve similar and paralleled concepts. The research developed is an additional contribution to the already large number of publications concerning the country of origin effect that aims to answer the question: How can firms mitigate/overcome a negative COE? Based on the literature and empirical results, a scheme was created (figure 1) that gathers all of the most relevant strategies that firms can adopt to combat the negative effect of country of origin. It is classified in four main groups: Group 1 (Defensive strategies to mask the COE); Group 2 (Defensive strategies to overcome the $\mathrm{COE}$ ); Group 3 (Offensive strategies to mask the COE) and Group 4 (Offensive strategies to overcome the $\mathrm{COE}$ ).

It is very important to make clear that some of the presented strategies do not solve the country of origin issue (Defensive strategies). Strategies such as choosing a foreign brand name or leveraging brands' secondary associations only mask the problem instead of overcoming it. However, cooperation, and particularly cooperation among firms from the same industry, as well as innovation and training investment seek to overcome COE, but they have not yet been successful.

Strategies from Groups 3 and 4 are more likely to effectively overcome the COE because of their proactivity. Some firms try to mask their national roots by developing an international filial. In this way, foreign customers don't perceive their products as their real origin. Group 4 represents the strategies that seek to overcome the COE most efficiently. Establishing and improving credibility through building connections with relevant stakeholders and gaining visibility by attending fairs and conferences proved to be the most efficient and fastest way to mitigate and overcome a negative COE and succeed internationally. In addition, by promoting their products and letting them become known in the international market, firms can avoid possible negative secondary and extrinsic associations. 
Figure 1. Strategies to Overcome Negative COE

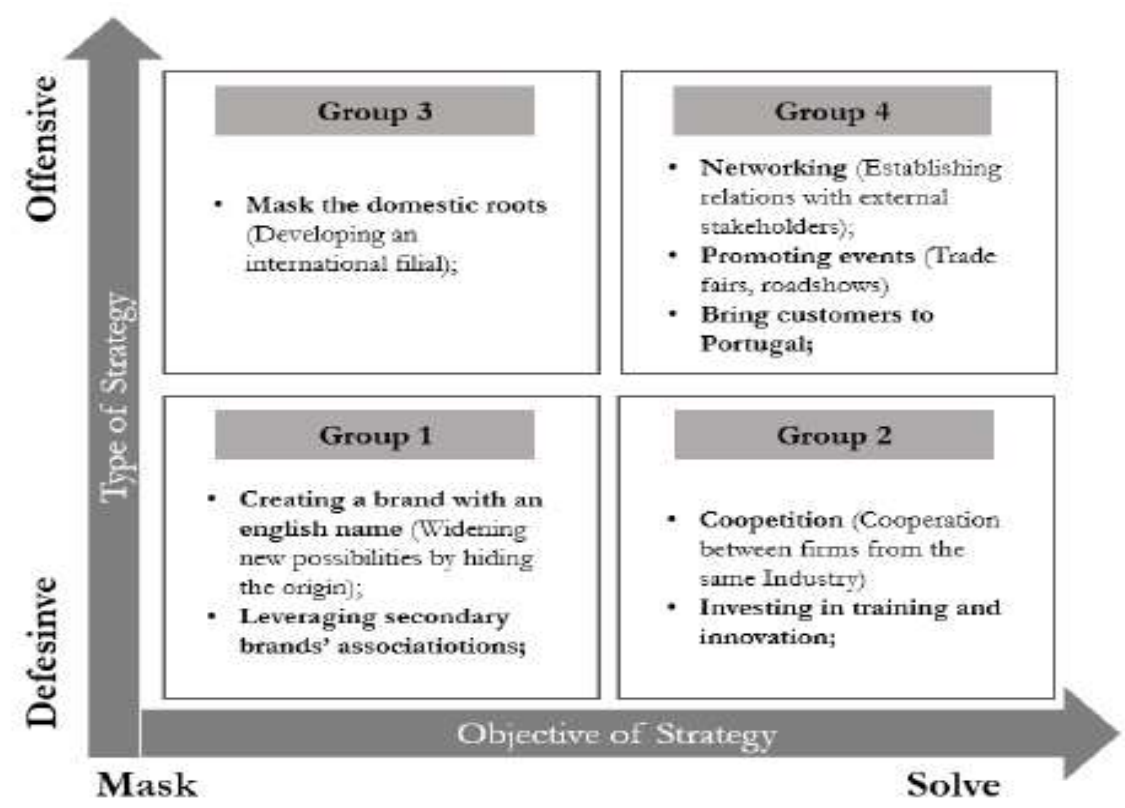

At a practical level, this research is of interest to management professionals to help them understand if their current internationalization strategies are effective in overcoming possible difficulties. It also serves to make the managers aware that there is still much to be done to improve the Portuguese image internationally. This could be in the form of investment in innovation, communication and training.

The results of this study should be interpreted considering certain limitations which naturally present opportunities for future research. Firstly, we considered only one entry mode (exports) and one single national identity. Future research could explore COE in other entry modes. Secondly, a small sample was considered based on a qualitative analysis. Future research could complement this study with a quantitative analysis and wider sample. Thirdly, the empirical results are based on Portuguese managers' opinions and experience only. Future studies could consider foreign entrepreneurs from this industry. Furthermore, this research could also be extended to other industries or countries, as well as different types of buyers (organizational buyer vs end-consumer).

\section{References}

Agrawal, J. and Kamakura, W. A. (1999). Country of Origin: A Competitive Advantage? International Journal of Research in Marketing, 16(4), 255-267 https://doi.org/10.1016/S0167-8116(99)00017-8

Al-Sulaiti, K. and Baker, M. (1998). Country of Origin Effects: A Literature Review. Marketing Intelligence and Planning, 16(3), 150-199 https://doi.org/10.1108/02634509810217309

Andehn, M. and L'espoir Decosta, J.-N.P. (2018). Re-imagining the Country-of-origin Effect: A Promulgation Approach. Journal of Product and Brand Management, 27 (7), 884-896 https://doi.org/10.1108/JPBM-11-2017-1666

Bilkey, W. J. and Nes, E. (1982). Country-of-Origin Effects on Product Evaluations. Journal of International Business Studies, 13(1), 89-99 https://doi.org/10.1057/palgrave.jibs.8490539

Cheah, I. Zainol, Z., and Phau, I. (2016). Conceptualizing Country-of-ingredient Authenticity of Luxury Brands. Journal of Business Research, 69 (12), 5819-5826 https://doi.org/10.1016/j.jbusres.2016.04.179

Costa, C., Carneiro, J. and Goldszmidt, R. (2016). A Contingent Approach to Country-of-origin Effects on Foreign Products Evaluation: Interaction of Facets of Country Image With Product Classes. International Business Review, 25(5), 1066-1075 https://doi.org/10.1016/j.ibusrev.2016.01.003

Eden, L., \& Miller, S. R. (2004). Distance Matters: Liability of Foreignness, Institutional Distance and Ownership Strategy, "Theories of the Multinational Enterprise: Diversity, Complexity and Relevance" (Vol. 16, pp. 187-221): Emerald Group Publishing Limited. 
Glaser, B. G \& Strauss, A., 1967. The Discovery of Grounded Theory: Strategies for Qualitative Research, Chicago, Aldine Publishing Company

Gregory, E., \& Ross, C. (1994). Consumer Perception of Product Quality and the Country-of-Origin Effect. Journal of International Marketing, 2(2), 49-62 https://doi.org/10.1177/1069031X9400200204

Han, C. M. (1989). Country Image: Halo or Summary Construct? Journal of Marketing Research, 26(2), $222-229$.

Hong, S.-T., \& Wyer, R. S. (1989). Effects of Country-of-Origin and Product-Attribute Information on Product

Evaluation: An Information Processing Perspective. Journal of Consumer Research, 16(2), 175-187 https://doi.org/10.1177/002224378902600208

Jacoby, J., Szybillo, G., \& Busato-Schach, J. (1977). Information Acquisition Behavior in Brand Choice Situations. Journal of Consumer Research, 3(4), 209-216 https://doi.org/10.1086/208669

Jiménez, N. H., \& San Martín, S. (2010). The role of country-of-origin, ethnocentrism and animosity in promoting consumer trust. The moderating role of familiarity. International Business Review, 19(1), 34-45 https://doi.org/10.1016/j.ibusrev.2009.10.001

Johanson, J., \& Vahlne, J.-E. (2009). The Uppsala internationalization process model revisited: From liability of foreignness to liability of outsidership. Journal of International Business Studies, 40(9), 1411-1431.

https://doi.org/10.1057/jibs.2009.24

Johansson, J. K., Douglas, S. P., \& Nonaka, I. (1985). Assessing the Impact of Country of Origin on Product Evaluations: A New Methodological Perspective. Journal of Marketing Research, 22(4), 388-396.

https://doi.org/10.1177/002224378502200404

Knight, G. (1999). Consumer preferences for foreign and domestic products. Journal of Consumer Marketing, 16(2), $151-162$.

https://www.emeraldinsight.com/doi/full/10.1108/07363769910260524

Keller, K.L. (1993). Conceptualizing, Measuring, and Managing Customer-Based Brand Equity. Journal of Marketing, $57,1-22$.

https://doi.org/10.1177/002224299305700101

Laroche, M., Papadopoulos, N., Heslop, L. and Mourali, M. (2005). The influence of country image structure on consumer evaluations of foreign products, International Marketing Review, 22 (1): 96-116.

https://doi.org/10.1108/02651330510581190

Leonidou, L. C. (2004). An analysis of the barriers hindering small business export development. Journal of small business management, 42(3), 279-302.

https://doi.org/10.1111/j.1540-627X.2004.00112.x

Luo, Y., \& Mezias, J. M. (2002). Liabilities of foreignness: Concepts, constructs, and consequences. Journal of International Management, 8(3), 217-221.

https://doi.org/10.1016/S1075-4253(02)00066-2

Luo, Y., Shenkar, O., \& Nyaw, M.-K. (2002). Mitigating liabilities of foreignness: Defensive versus offensive approaches. Journal of International Management, 8(3), 283-300.

https://doi.org/10.1016/S1075-4253(02)00073-X

Maheswaran, D. (1994). Country of Origin as a Stereotype: Effects of Consumer Expertise and Attribute Strength on Product Evaluations (Vol. 21).

Maruyama, M., \& Wu, L. (2015). Overcoming the Liability of Foreignness in International Retailing: A Consumer Perspective. Journal of International Management, 21(3), 200-210.

https://doi.org/10.1016/j.intman.2015.07.001

Niss, H. (1996). Country of origin marketing over the product life cycle: A Danish case study. European journal of marketing, 30(3), 6-22

https://www.emeraldinsight.com/doi/full/10.1108/03090569610107409

Rezvani, S., Dehkordi, G. J., Rahman, M. S., Fouladivanda, F., Habibi, M., \& Eghtebasi, S. (2012). A conceptual study on the country of origin effect on consumer purchase intention. Asian Social Science, 8(12), 205-215.

doi:10.5539/ass.v8n12p205

Shahin, A., Kazemi, A., \& Mahyari, H. (2013). How Consumer's Perception of Country of Origin affects Brand Equity: A Case Study in Iran. Journal of Basic and Applied Scientific Research, 3(2), 1203-1210.

DOI: 10.5829/idosi.mejsr.2012.12.6.1755

Schatzle. S. and Jacob, F. (2019). Stereotypical supplier evaluation criteria as inferred from country-of-origin information. Industrial Marketing Management, 78, 250-262 https://doi.org/10.1016/j.indmarman.2017.06.014

Schooler, R.D. (1965), Product bias in the Central American common market, Journal of Marketing Research, Vol 2, No 4, pp 394-397 https://doi.org/10.1177/002224376500200407 
Silva, S., \& Saraiva, L. (2016). Understanding Changes on the Country-of-origin Effect of Portugal, Studia Universitatis Babe-Bolyai Oeconomica (Vol. 61, pp. 3).

DOI: $10.1515 /$ subboec-2016-0001

Suh, Y., Hur, J.Y., and Davies, G. (2016). Cultural appropriation and the country of origin effect. Journal of Business Research, 69 (8), 2721-2730.

https://doi.org/10.1016/j.jbusres.2015.11.007

Suter, M. B., Borini, F. M., Floriani, D. E., da Silva, D., \& Polo, E. (2018). Country-of-origin image (COI) as a countryspecific advantage (CSA): Scale development and validation of COI as a resource within the firm perspective. Journal of Business Research, 84, 46-58.

https://doi.org/10.1016/j.jbusres.2017.11.006

Thakor, M. (1996). Brand origin: conceptualization and review. Journal of Consumer Marketing, 13(3), 27-42.

https://doi.org/10.1108/07363769610147929

Usunier, J.-C., \& Cestre, G. (2007). Product Ethnicity: Revisiting the Match between Products and Countries. Journal of International Marketing, 15(3), 32-72.

https://doi.org/10.1509/jimk.15.3.32

Yunus, N. S. N. M., \& Rashid, W. E. W. (2016). The Influence of Country-of-origin on Consumer Purchase Intention:

The Mobile Phones Brand from China. Procedia Economics and Finance, 37(Supplement C), 343-349 https://doi.org/10.1016/S2212-5671(16)30135-6 